\title{
SARS COV-2: Exploring the Virus of the Century
}

\author{
Arpita Saxena', Sukanya Gangopadhyay ${ }^{2}$, Shilpa Suneja ${ }^{2}$ \\ ${ }^{1}$ Senior Resident, Department of Biochemistry, VMMC and Safdarjung Hospital, New Delhi \\ ${ }^{2}$ Associate Professor, Department of Biochemistry, VMMC and Safdarjung Hospital, New Delhi
}

Corresponding Author: Sukanya Gangopadhyay

\begin{abstract}
Coronaviruses comprise a large family of viruses that cause respiratory and intestinal infections in animals and humans. This recent outbreak of unusual respiratory disease plaguing the entire world has been named severe acute respiratory syndrome coronavirus 2 (SARS$\mathrm{CoV}-2$ ) on the basis of phylogenetic analysis of related coronaviruses. Its transmission occurs mainly through airborn, fomite and other modes. Structurally, it is similar to other coronaviruses and has four major structural proteins; the spike surface glycoprotein (S), small envelope protein (E), matrix protein (M) and nucleocapsid protein $(\mathrm{N})$. The $\mathrm{M}$ protein is most abundant and is responsible for intracellular formation of virus particles. S protein induces antibody generation and is involved in intracellular virus entry. Drug combinations are being tried on the basis of structural and genomic knowledge of the virus. Various researchers have found that the SARS CoV2 has many strains among which L type is most pathogenic and D614 type is most infective. All this information has been collected in this review to understand the virus behind this calamity in depth and to make it handy for the researchers to search literature related to SARS COV2.
\end{abstract}

Key Words: SARS COV2, spike glycoprotein, L type strain, D614 strain

\section{INTRODUCTION}

COVID 19 is a 21 st century global epidemic that has shaped the modern world irreversibly. The virus has largely left the health care system of all countries baffled in relation to variable infection, variable post exposure antibody titers, variable natural immunity, symptom display, morbidity grade and various mortality. This review is an attempt to identify the virus by compiling the knowledge gained so far.

\section{Origin and nomenclature}

Corona viruses include a large family of viruses that cause respiratory and intestinal infections in animals and humans. There are seven types of human coronavirus $(\mathrm{HCoV})$ that have a broad spectrum ranging from colds to influenza including Middle East Respiratory Syndrome (MERS) and Acute Respiratory Syndrome (SARS) [1]. A total of seven HCoVs are of zoonotic origin from bats, rats, or pets [2,3].

This unusual lung disease, which initially causes pneumonia, was first named by WHO as 2019-nCoV in Wuhan, China [4-6]. On 11 February 2020, it was renamed Coronavirus Disease 2019 (COVID-19) by WHO. The Coronavirus Study Group (CSG) of the International Committee on Virus Classification recommends that 2019-nCoV be designated as Acute Respiratory Syndrome Coronavirus 2 (SARS-CoV-2) based on phylogenetic analysis of related coronaviruses [8].

SARS-CoV-2 is estimated to have originated from the local seafood market, that illegally sold animals, including chickens, bats and snakes in Wuhan. Two recent studies showed in 2019 that bats [9] or snakes [10] as a natural reservoir. However, based on the latest announcement from the WHO on 23 January 2020, the origin of the $2019 \mathrm{nCoV}$ is not yet known [11]. 
There are many other skeptical theories floating around the origin of the $\mathrm{CoV}$ pandemic. According to one, the virus was engineered as a bioweapon or accidentally escaped from a genetic engineering research laboratory due to a lack of safety protocols [12].

\section{Transmission}

The transmission of SARS-CoV-2 is through direct/indirect contact with infected person through infected secretions such as saliva and respiratory secretions or droplets $(>10 \mu \mathrm{m}$ in diameter) [13-22].

\section{Airborne transmission}

Exhaled air physics and flow physics have formed hypotheses about the possible mechanism of transmission of SARS-CoV-2 by aerosols [23-26]. These theories suggest that microscopic aerosols are generated by respiratory droplets and the susceptible person can get infected by the aerosols provided the aerosols contain the virus in sufficient quantity to cause infection within the recipient. However, the amount respiratory droplets that evaporate to generate aerosols and the infectious dose of viable SARS-CoV-2 which cause infection in another person are not known, but that has been studied for other respiratory viruses [27]. A recent experimental model concluded that healthy individuals can produce infective aerosols while coughing and talking [28], and another model suggests greater variation in individuals in terms of increasing particle emission rates during speech [29]. Among the samples for which SARS-CoV-2 RNA was detected, a low amount of RNA was present in large amounts in the air and one study that found SARS-CoV-2 RNA in air samples reported inability to identify viable virus [30].

\section{Fomite transmission}

Respiratory secretions or droplets expelled by infected individuals can contaminate surfaces and objects leading to fomite generation. Viable SARS-CoV-2 virus and/or RNA detected by RT-PCR are often found on those surfaces for hours to days, based on the ambient environment (including temperature and humidity) and the sort of surface, especially at high concentration in health care facilities where COVID-19 patients were being treated [3141]. Therefore, transmission can also occur indirectly through touching surfaces or objects contaminated with virus from an infected person (e.g. stethoscope or thermometer)and then touching own mouth, nose, or eyes.

\section{Other modes of transmission}

SARS-CoV-2 RNA has also been detected in other biological samples, including the urine and feces of some patients [42-46]. One study found viable SARS-CoV-2 in the urine of some patient [47]. Three studies have cultured SARSCoV-2 from stool specimens [44-49]. Upto present date, however, there are no published reports of transmission of SARSCoV-2 through feces, urine or semen.

Detection of viral RNA doesn't necessarily mean that an individual is infectious and ready to transmit the virus to a different person. Factors that determine the risk of transmission are whether the virus can be replicated or whether the patient has cough-like symptoms, usually leading to the spread of infection. Usually 510 days after infection with SARS-CoV-2, the infected individual starts to produce neutralizing antibodies. Binding of those neutralizing antibodies to the virus is predicted to scale back the danger of virus transmission [50-53].

\section{Structure}

Coronaviruses are spherical viruses which are enveloped and their size ranges from 80 to $120 \mathrm{~nm}$. They have a 5 'capped, single-strand positive Sense RNA gene that is between 26.2 and $31.7 \mathrm{~kb}$ long, the longest of all RNA viruses. . They have a crown (Coronum is the Latin term for 'crown') like appearance due to presence of spike glycoproteins on the envelope under an electron microscope [54]. This spike 
surface glycoprotein plays an essential role in binding to receptors on the host cell and determines host tropism [55, 56] (Figure 1). Other major structural proteins are the small envelope protein $(\mathrm{E})$, matrix protein $(\mathrm{M})$, and nucleocapsid protein $(\mathrm{N})$.

Membrane (M) glycoproteinis the most abundant structural protein spanning the membrane bilayer three times and leaving a short NH2-terminal domain outside the virus and a long $\mathrm{COOH}$ terminus (cytoplasmic domain) inside the virion [57]. Spike protein (s) as a type I membrane glycoprotein forms peplomers. In fact, the main inducer of neutralizing antibodies is $S$ protein. Molecular interaction between envelope proteins determines the structure of coronavirus membranes. Drugs like tunicamycin makes coronavirus grow and produces spikeless, noninfectious virions that contain $\mathrm{M}$ proteins $[57,58]$.

\section{Genome and multiplication}

The ordination of coronaviruses, with a mean size of twenty six - 32kbp, includes roughly half-dozen to 11open reading frames (ORFs) [59]. The primary ORF (representing roughly sixty seven of the whole genome) encodes the replicase proteins, the structural macromolecule genes in a very mounted order: (HE)-S-EM-N (Figure 1A) and sixteen non-structural proteins (nsps), whereas the remaining ORFs write accent proteins and structural proteins [60]. Genomic sequence analysis of COVID-19 showed half of one mile identity with 2 bat-derived severe acute metabolic process syndrome (SARS)-like coronaviruses $[61,62]$ indicating that these mammals square measure the foremost probably link between COVID-19 and humans.

The ribonucleic acid genomes of COVID-19 is twenty nine. $9 \mathrm{~K}$ that dissent from SARS- CoV and MERS-CoV, that square measure roughly, $27.9 \mathrm{~K}$ and $30.1 \mathrm{~K}$ in size [61].The COVID-19 complete ordination contains of fourteen open reading frames (ORFs) secret writing twenty seven proteins. Sequence analysis discovered that COVID- 19 has $>80 \%$ identity with SARS$\mathrm{CoV}$ and $50 \%$ with MERS- CoV that originated in bats $[62,63]$.

The Structural proteins square measure encoded by the four structural genes, as well as spike (S), envelope (E), membrane $(\mathrm{M})$ and nucleocapsid $(\mathrm{N})$ genes [64-66].

The ordination is packaged in a very complicated nucleocapsid which is whorled in form encircled by a host-derived lipide bilayer. Some coronaviruses additionally contain a hemagglutinin esterase (HE) additionally $\mathrm{M}$ and $\mathrm{E}$ macromolecules square measure concerned in virus assembly whereas the spike protein is that the leading negotiant of infectious agent entry. The latter is additionally the principal player in crucial host vary $[67,68]$. Coronaviruses use a ribonucleic acid-dependent RNA enzyme $(\mathrm{RdRp})$ complicated for the replication of their ordination, and for sub-genomic transcription of their genes $[69,70]$.

\section{Mode of infection in host}

The envelope-encapsulated spike macromolecule initial binds to the host receptor then mediates the entry of the coronavirus into the host cells, fusing the infectious agent and host membranes. an outlined receptor-binding domain (RBD) of SARS-CoV spike specifically acknowledges its host receptor angiotensin-converting protein a pair of (ACE2) [71] (Table 1).

Table 1 Viral proteins and their functions

\begin{tabular}{|l|l|}
\hline $\begin{array}{l}\text { VIRAL } \\
\text { PROTEIN }\end{array}$ & FUNCTION \\
\hline Spike protein (S) & $\begin{array}{l}\text { facilitates viral entry into target } \\
\text { cells }\end{array}$ \\
\hline $\begin{array}{l}\text { Membrane protein } \\
(\mathrm{M})\end{array}$ & $\begin{array}{l}\text { Facilitates budding process of } \\
\text { coronaviruses }\end{array}$ \\
\hline $\begin{array}{l}\text { Envelope protein } \\
(\mathrm{E})\end{array}$ & Viral assembly and budding \\
\hline
\end{tabular}




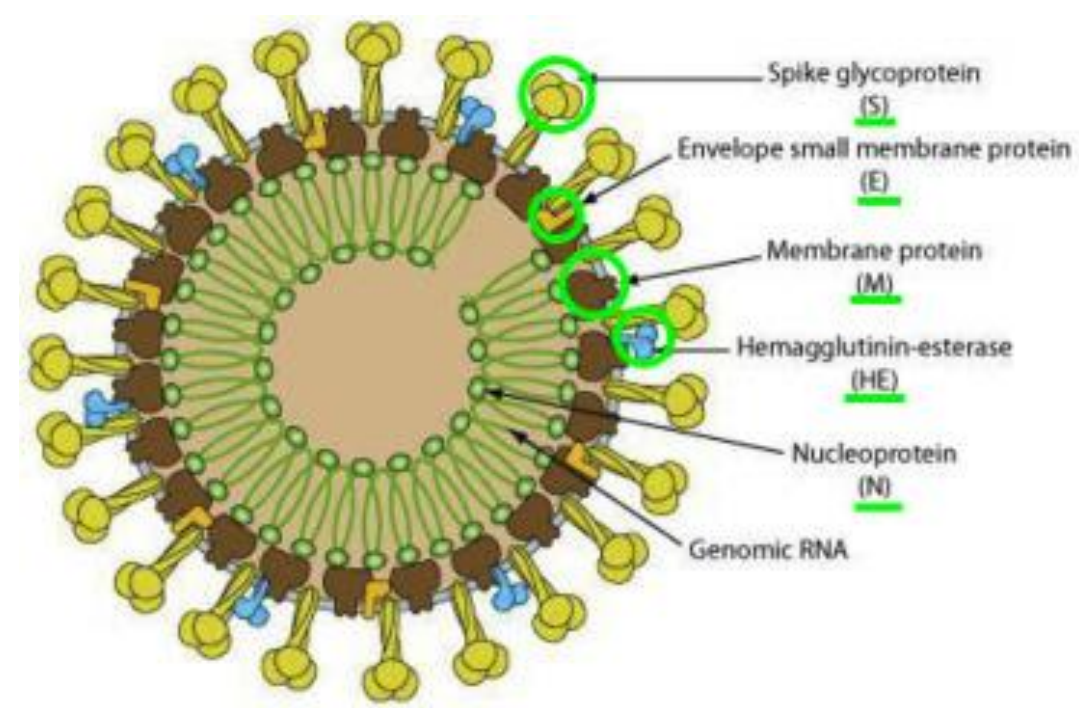

Fig 1 Schematic diagram of a coronavirus (http://ruleof6ix.fieldofscience.com/2012/09/a-new-coronavirus-should-you-care.html).

The spike (s) protein of coronaviruses leads to viral entry into target cells. Penetration depends on the binding of $\mathrm{S} 1$, the surface unit of the $\mathrm{S}$ protein, to the cell receptor, which facilitates viral attachment to the target surface. Furthermore, entry requires $\mathrm{S}$ protein priming through cellular proteases, which leads to the $\mathrm{S}$ protein cleavage at sites of $\mathrm{S} 1$ / S2 and S2 and allows the fusion of viral and cellular membranes, a process carried out by the $S 2$ unit. SARS-S engages the antiotensin-converting enzyme 2 (ACE2) as the entry receptor [72] and uses the cellular serine protein TMPRSS2 for $\mathrm{S}$ protein priming [73-75].

The virus infects its human host, replicates and eventually spreads from person to person using its accessory protein. The six secondary proteins in the SARSCoV2 gene are ORF3a, ORF6a, ORF7a, ORF7b, ORF8 and ORF10, which play important roles in the viral life cycle and are responsible for its pathogenesis.

These proteins have least homology in amino acid sequence with accessory proteins of other coronaviruses. They contribute to virus virulence though it does not directly affect the virus release, stability and pathogenesis [79]. The spike protein mutations could change the tropism of a virus and increase viral pathogenesis [76].

\section{Strains and mutations}

A study conducted by Liangsheng Zhang et al obtained 97 complete genomes of COVID-19 samples and inferred their evolutionary relationships. Overall, they found upto 3 mutations among the majority of COVID-19 genomes and 95 variable sites. Their phylogenetic relationships suggested the presence of two major types of COVID-19, namely Type I and II. The genomes of the two types mainly differ at three sites which are 8750, 28112, and 29063, based on MN938384.1's genome coordinates [77].

The Type I strains can be further divided into Type IA and IB depending on the nucleotide at the site 29063 The number of genomes belonging to Type IA, IB and II are 10, 18, and 69, respectively. This finding suggests that the Type II strains are dominant in the infected populations [77].

Tang et al. also carried out extensive study on the circulating SARS-CoV2 strains and divided the virus into two major types of SARS-CoV2 defined by two single nucleotide polymorphisms (SNPs) that show complete linkage. They analysed 103 SARS-CoV-2 virus strains and found that 101 showed complete linkage between the two SNPs: 72 strains exhibited a "CT" haplotype (defined as "L" type because $\mathrm{T} 28,144$ is in the codon of Leucine) i.e major type and 29 strains exhibited a "TC" haplotype (defined as " $\mathrm{S}$ " type because 
C28,144 is in the codon of Serine) i.e. minor type at these two sites. Thus they categorized the SARS-CoV-2 viruses into two major types, with $\mathrm{L}$ being the major type $(\sim 70 \%)$ and $\mathrm{S}$ being the minor type $(\sim 30 \%)$ [78].

Korber et al. presented evidence that there are now more SARS-CoV-2 viruses circulating in the human population globally that have the G614 form of the Spike protein versus the D614 form that was originally identified from the first human cases in Wuhan, China [79]. There is a mutational change in the amino acid at position 614 , from $D$ (aspartic acid) to $G$ (glycine) - so, D-614-G. Further studies show that patients infected with G614 release more viral nucleic acid compared to those with D614, while G614-carrying viruses show significantly higher in vitro infectious strains than their D614 counterparts [79].

Avoiding the confusion, WHO has assigned letters of the Greek alphabet to name the key variants of SARS-CoV-2 in May 2021. Currently, upto delta variants are in circulation. However, these labels do not replace existing scientific names which will continue to be used in research.

\section{CONCLUSIONS}

The SARS COV2 pandemic has crippled the global economy like never before. It is imperative for the survival of mankind to overcome this disaster and prevent such catastrophes in future. As knowledge is power, this review is an attempt to collect all knowledge gained so far on this coronavirus variant so as to empower the academicians and researchers for further action.

\section{Declaration of Interests}

The authors declare no conflict of interests.

\section{Acknowledgement: None}

Source of Funding: None

\section{REFERENCES}

1. A. Du Toit, Outbreak of a novel coronavirus, Nat. Rev. Microbiol. 2020; 18: 123.

2. Su S, Wong G, Shi W, Liu J.,Lai ACK, Zhou J, et al. Epidemiology, Genetic Recombination, and Pathogenesis of Coronaviruses.Trends Microbiol. 2016; 24(6): 490-502.

3. Li X, Song Y, Wong G. Bat origin of a new human coronavirus: there and back again. Cui J Sci China Life Sci. 2020; 63(3): 461-2.

4. Zhu N, Zhang D, Wang W, Li X, Yang B, Song $\mathrm{J}$ et al. A Novel Coronavirus from Patients with Pneumonia in China, 2019. N Engl J Med. 2020; 382(8):727-33.

5. Zhou $P$, Yang XL, Wang XG, Hu B, Zhang L, Zhang $\mathrm{W}$ et al. A pneumonia outbreak associated with a new coronavirus of probable bat origin. Nature. 2020; 579 (7798): 270-3.

6. Wu F, Zhao S, Yu B, Chen YM, Wang W, SongZG, et al. A new coronavirus associated with human respiratory disease in China. Nature 2020; 579 (7798): 265-9.

7. WHO. Coronavirus disease 2019. https://www.

who.int/emergencies/diseases/

novelcoronavirus-2019 (assessed on Jan 1, 2021).

8. Coronaviridae Study Group of the International Committee on Taxonomy of Viruses., Gorbalenya, A.E., Baker, S.C. et al. The species Severe acute respiratory syndrome-related coronavirus: classifying 2019-nCoV and naming it SARS-CoV-2. Nat Microbiol. 2020; 5: 536-44.

9. Xu X, Chen P, Wang J, Feng J, Zhou H, Li X, Zhong W, Hao P. Evolution of the novel coronavirus from the ongoing Wuhan outbreak and modeling of its spike protein for risk of human transmission. Sci China Life Sci. 2020; 63(3): 457-60.

10. Ji W, Wang W, Zhao X, Zai J, Li X. Cross-species transmission of the newly identified coronavirus 2019-nCoV. J Med Virol. 2020; 92(4): 433-40.

11. WHO. Statement on the first meeting of the International Health Regulations (2005) Emergency Committee regarding the outbreak of novel coronavirus (2019- 
nCoV) Released on 23 January 2020. https://www.who.int/news/item/23-012020-statement-on-the-meeting-of-theinternational-health-regulations-(2005)emergency-committee-regarding-theoutbreak-of-novel-coronavirus-(2019ncov) (assessed on 1/1/2021).

12. The conspiracy theories about the origins of the coronavirus, debunked. Available at https://www.vox.com/2020/3/4/21156607/ how-did-the-coronavirus-get-startedchina- wuha n-lab (assessed on 1/1/2021).

13. Liu J, Liao X, Qian S, Yuan J, Wang F, Liu Y, et al. Community Transmission of Severe Acute Respiratory Syndrome Coronavirus 2, Shenzhen, China, 2020. Emerg Infect Dis. 2020; 26: 1320-3.

14. Chan JF-W, Yuan S, Kok K-H, To KKW, Chu H, Yang J, et al. A familial cluster of pneumonia associated with the 2019 novel coronavirus indicating person-to-person transmission: a study of a family cluster. Lancet. 2020; 395: 14-23.

15. Huang C, Wang Y, Li X, Gao C, Wang Y, $\mathrm{Gu} \mathrm{X}$, et al. Clinical features of patients infected with 2019 novel coronavirus in Wuhan, China. Lancet. 2020; 395: $497-$ 506.

16. Burke RM, Midgley CM, Dratch A, Fenstersheib A, Houpt T, Holshue M et al. Active Monitoring of persons exposed to patients with confirmed COVID-19 United States, January-February 2020. MMWR Morb Mortal Wkly Rep. 2020; 69: 245-6.

17. Report of the WHO-China Joint Mission on Coronavirus Disease 2019 (COVID19) 16-24 February 2020. Geneva: World Health Organization; 2020 (available at https://www.who.int/docs/defaultsource/coronaviruse/who-china-jointmission-oncovid-19-final-report.pdf). (Assessed on 2/1/2021).

18. Hamner L, Dubbel P, Capron I, Ross A, Jordan A, Lee J et al. High SARS-CoV-2 Attack Rate Following Exposure at a Choir Practice - Skagit County, Washington, March 2020. MMWR Morb Mortal Wkly Rep. 2020; 69: 606-10.

19. Ghinai I, McPherson TD, Hunter JC, Kirking HL, Christiansen D, Joshi K et al. First known person-to-person transmission of severe acute respiratory syndrome coronavirus 2 (SARS-CoV-2) in the USA. Lancet. 2020; 395: 1137-44.

20. Pung R, Chiew CJ, Young BE, Chin S, Chen M, Clapham $\mathrm{H}$ et al. Investigation of three clusters of COVID-19 in Singapore: implications for surveillance and response measures. Lancet. 2020; 395: 1039-46.

21. Luo L, Liu D, Liao X, Wu A, Jing Q, Zheng $\mathrm{J}$ et al. Modes of contact and risk of transmission in COVID-19 among close contacts (pre-print). Med Rxiv.2020.

22. Infection Prevention and Control of Epidemic-and Pandemic-prone Acute Respiratory Infections in Health Care. Geneva: World Health Organization; 2014.

23. Mittal R, Ni R, Seo J-H. The flow physics of COVID-19. J Fluid Mech. 2020; 894.

24. Bourouiba L. Turbulent GasClouds and Respiratory Pathogen Emissions: Potential Implications for Reducing Transmission of COVID-19. JAMA. 2020; 323(18): 1837-8.

25. Asadi S, Bouvier N, Wexler AS, Ristenpart WD. The coronavirus pandemic and aerosols: Does COVID-19 transmit via expiratory particles? Aerosol Sci Technol. 2020; 54: 635-8.

26. Morawska L, Cao J. Airborne transmission of SARS-CoV-2: The world should face the reality. Environ Int. 2020; 139: 105730.

27. Gralton J, Tovey TR, McLaws ML. Respiratory Virus RNA is detectable in airborne and droplet particles. J Med Virol. 2013;85:2151-9.

28. Somsen GA, van Rijn C, Kooij S, Bem RA, Bonn D. Small droplet aerosols in poorly ventilated spaces and SARS-CoV2 transmission. Lancet Respir Med. 2020; 8(7): 658-69.

29. Asadi S, Wexler AS, Cappa CD, Barreda S, Bouvier NM, Rstenpart WD. Aerosol emission and superemission during human speech increase with voice loudness. Sci Rep. 2019; 9: 2348.

30. Santarpia JL, Rivera DN, Herrera V, Morwitzer MJ, Creager HM, Santarpia $\mathrm{GW}$ et al. Aerosol and surface contamination of SARS-CoV-2 observed 
in quarantine and isolation care. Sci Rep. 2020; 10: 12732.

31. Doremalen NV, Bushmaker T, Morris DH, Holbrook MG, Gamble A, Williamson BN, et al. Aerosol and surface stability of SARS-CoV-2 as compared with SARS-CoV-1. N Engl J Med. 2020; 382: 1564-7.

32. Chia PY, Coleman KK, Tan YK, Ong SWX, Gum M, Lau SK, et al. Detection of air and surface contamination by SARSCoV-2 in hospital rooms of infected patients. Nat Comm. 2020; 11(1): 2800.

33. Guo ZD, Wang ZY, Zhang S, Li X, Li L, $\mathrm{Li} C$, et al. Aerosol and Surface Distribution of Severe Acute Respiratory Syndrome Coronavirus 2 in Hospital Wards, Wuhan, China, 2020. Emerg Infect Dis. 2020; 26(7) : 1583-91.

34. Zhou J, Otter J, Price JR, Cimpeanu C, Garcia DM, Kinross J, et al. Investigating SARS-CoV-2 surface and air contamination in an acute healthcare setting during the peak of the COVID-19 pandemic in London (pre-print).Clinical Infectious Diseases. 2020; Ciaa,905.

35. Ma J, Qi X, Chen H, Li X, Zhan Z, Wang $\mathrm{H}$, et al. Exhaledbreathis a significant source of SARS-CoV-2 emission (preprint).MedRxiv.2020.

36. Ong SWX, Tan YK, Chia PY, Lee TH, Ng OT, Wong MSY et al. Air, Surface Environmental, and Personal Protective Equipment Contamination by Severe Acute Respiratory Syndrome Coronavirus 2 (SARS-CoV-2) From a Symptomatic Patient. JAMA. 2020; 323 (16): 1610-2.

37. Yamagishi T, Ohnishi M, Matsunaga N, Kakimoto K, Kamiya H, Okamoto K et al. Environmental Sampling for Severe Acute Respiratory Syndrome Coronavirus 2 During a COVID-19 Outbreak on the Diamond Princess Cruise Ship. J Infect Dis. 2020; 222(7): 1098-102.

38. Döhla M, Wilbring G, Schulte B. SARSCoV-2 in environmental samples of quarantined households (pre-print). MedRxiv. 2020.

39. Cheng VCC, Wong SC, Chen JHK. Escalating infection control response to the rapidly evolving epidemiology of the coronavirus disease 2019 (COVID-19) due to SARS-CoV-2 in Hong Kong. Infect Control Hosp Epidemiol. 2020; 41: 493-8.

40. Matson MJ, Yinda CK, Seifert SN, Bushmaker T, Fischer RJ, Doremarlen $\mathrm{VN}$, et al. Effect of Environmental Conditions on SARS-CoV-2 Stability in Human Nasal Mucus and Sputum. Emerg Infect Dis. 2020; 26(9) : 2276-8.

41. Pastorino B, Touret F, Gilles M, de Lamballerie $\mathrm{X}$, Charrel RN. Prolonged Infectivity of SARS-CoV-2 in Fomites. Emerg Infect Dis. 2020; 26(9): 2256-7.

42. Guan WJ, Ni ZY, Hu Y, Liang WH, Ou CQ, He JX, et al. Clinical Characteristics of Coronavirus Disease 2019 in China. New Engl J Med. 2020; 382: 1708-20.

43. Pan Y, Zhang D, Yang P, Poon LLM, Wang Q. Viral load of SARS-CoV-2 in clinical samples. Lancet Infect Dis. 2020; 20(4): 411-2.

44. Wang W, Xu Y, Gao R, Lu R, Han K, Wu $\mathrm{G}$, et al. Detection of SARS-CoV-2 in Different Types of Clinical Specimens. JAMA. 2020; 323(18): 1843-4.

45. Wu Y, Guo C, Tang L, Hong Z, Zhou J, Dong $X$, et al. Prolonged presence of SARS-CoV-2 viral RNA in faecal samples. Lancet Gastroenterol Hepatol. 2020; 5(5): 434-5.

46. Zheng S, Fan J, Yu F, Feng B, Lou B, Zou $\mathrm{Q}$, et al. Viral load dynamics and disease severity in patients infected with SARS CoV-2 in Zhejiang province, China, January-March 2020: retrospective cohort study. BMJ. 2020; 369: 1443.

47. Sun J, Zhu A, Li H, Zheng Z, Chen Z, Shi $Y$, et al. Isolation of infectious SARSCoV-2 from urine of a COVID-19 patient. Emerg Microbes Infect. 2020; 9: 991-3.

48. Xiao F, Sun J, Xu Y, Li F, Huang X, Li H et al. Infectious SARS-CoV-2 in Feces of Patient with Severe COVID-19. Emerg Infect Dis. 2020; 26(8): 1920-2.

49. Zhang Y, Chen C, Zhu S, Shu C, Wang D, Song J, et al. Isolation of 2019-nCoV from a stool specimen of a laboratory confirmed case of the coronavirus disease 2019 (COVID-19). China CDC Weekly. 2020; 2: 123-4.

50. Wolfel R, Corman VM, Guggemos W, Seilmaier M, Zange S, Muller MA et al. Virological assessment of hospitalized 
patients with COVID-19. Nature. 2020; 581: 465-9.

51. Van Kampen JJA, Van de Vijner DAMC, Fraaij PLA, et al. Personal communication with van Kampen JJA. Shedding of infectious virus in hospitalized patients with coronavirus disease 2019 COVID19: duration and key determinants. (Preprint) Medrxiv. 2020.

52. Klasse PJ. Neutralization of Virus Infectivity by Antibodies: Old Problems in New Perspectives. Adv Biol. 2014; 2014: 157895.

53. Atkinson B, Petersen E. SARS-CoV-2 shedding and infectivity. Lancet. 2020; 395(10233): 1339-40.

54. Killerby ME, Biggs HM, Haynes A, Dahl RM, et al. J of Clin Vir.2018; 101: 52-6

55. Li F. Structure, Function, and Evolution of Coronavirus Spike Proteins. Annu. Rev. Virol. 2016; 3: 237-61.

56. Zhu Z., Zhang Z., Chen W., Cai Z., Ge X., Zhu H., Jiang T., Tan W., Peng Y. Predicting the receptor-binding domain usage of the coronavirus based on kmer frequency on spike protein. Infect. Genet. evol. 2018; 61: 183-4.

57. Haan C, Kuo L, Masters PS, Vennema $\mathrm{H}$, Rottier PJM. Coronavirus particleassembly: primary structure requirements of the membrane protein. $\mathrm{J}$ Virol.1998; 72 (8): 6838-50.

58. Woo PCY, Huang Y, Lau SKP, Yuen KY. Coronavirus genomics and bioinformatics analysis Viruses.2010; 2 (8): 1804-20.

59. Song Z, Xu Y, Bao L, Zhang L, Yu P, Qu $\mathrm{Y}$ et al. From SARS to MERS, Thrusting Coronaviruses into the Spotlight. Viruses. 2019; 11: E59.

60. Cui J, Li F, Shi ZL. Origin and evolution of pathogenic coronaviruses. Nat Rev Microbiol. 2019; 17: 181-92.

61. Wu A, Peng Y, Huang B, Ding X, Wang $X$, Niu $P$, et al. Genome composition and divergence of the novel coronavirus (2019-nCoV) originating in China. Cell Host \& Microbe. 2020; 27(3): 325-8.

62. Cheepsattayakorn A, Cheepsattayakorn R. Proximal origin and phylogeneticanalysis of COVID-19 (2019-nCoV or SARS-
CoV-2). EC Microbiol. 2020. SI 02: 0912.

63. Guo YR, Cao QD, Hong ZS, Tan YY, Chen SD, Jin HJ, et al. The origin, transmission and clinical therapies on coronavirus disease. Mil Med Res. 2020; 7(1): 11.

64. Wu A, Peng Y, Huang B, Ding X, Wang $X$, Niu P. Genome composition and divergence of the novel coronavirus (2019-nCoV) originating in China. Cell Host Microbe. 2020; 27(3): 325-8.

65. Lu R, Zhao X, L Ji, Niu P, Yang B, Wu $\mathrm{H}$, et al. Genomic characterisation and epidemiology of 2019 novel coronavirus: implications for virus origins and receptor binding. Lancet. 2020; 395 (10224): 56574

66. Chen Y, Liu Q, Guo D. Emerging coronaviruses: Genome structure, replication, and pathogenesis. J Med Virol. 2020 Apr;92(4):418-23.

67. Perlman S, Netland J. Coronaviruses post-SARS: Update on replication and pathogenesis. Nat. Rev. Microbiol. 2009; 7: 439-50.

68. Enjuanes L, Almazan F, Sola I, Zuniga, S. Biochemical aspects of coronavirus replication and virus-host interaction. Annu. Rev. Microbiol. 2006; 60: 211-30.

69. Snijder EJ, Decroly E, Ziebuhr J. The Nonstructural proteins directing Coronavirus RNA Synthesis and Processing. Adv Virus Res. 2020; 96: 59126.

70. Posthuma CC, Velthuis TAJW, Snijder EJ. Nidovirus RNA polymerases: Complex enzymes handling exceptional RNA genomes. Virus Res. 2017; 234: 5873.

71. Li F. Structure, function, and evolution of coronavirus spike proteins. Annu Rev Virol. 2016; 3: 237-61.

72. Glowacka I, Bertram S, Müller MA et al. Evidence that TMPRSS2 activates the severe acute respiratory syndrome coronavirus spike protein for membrane fusion and reduces viral control by the humoral immune response. J Virol. 2011; 85: 4122-34.

73. Matsuyama S, Nagata N, Shirato K et al. Taguchi Efficient activation of the severe 
acute respiratory syndrome coronavirus spike protein by the transmembrane protease TMPRSS2. J Virol. 2010; 84: 12658-64.

74. Shulla A, Sargent TH, Subramanya G, Zhao J, Perlman S, Gallagher T. A transmembrane serine protease is linked to the severe acute respiratory syndrome coronavirus receptor and activates virus entry. J Virol. 2011; 85: 873-82.

75. Li W, Moore MJ, Vasilieva N, et al. Angiotensin-converting enzyme 2 is a functional receptor for the SARS coronavirus Nature. 2003; 426: 450-4.

76. Xu K, Zheng BJ, Zeng R, Lu W, Lin YP, Xue L, et al., Severe acute respiratory syndrome coronavirus accessory protein $9 \mathrm{~b}$ is a virion-associated protein, Virology. 2009; 388: 279-85.

77. Zhang L, Yang J, Zhang Z, Lin Z. Genomic variations of COVID-19 suggest multiple outbreak sources of transmission. medRxiv preprint.

78. Tang X, Wu C, Li X, Song Y, Yao X, Wu X, Duan Y, Zhang H, Wang Y, Qian Z, Cui J, Lu J. On the origin and continuing evolution of SARS-CoV-2. Natl Sci Rev. 2020: nwaa036.

79. Korber B, Fischer WM, Gnanakaran S, Yoon $\mathrm{H}$, Theiler $\mathrm{J}$, Abfalterer $\mathrm{W}$ et al. Tracking Changes in SARS-CoV-2 Spike: Evidence that D614G Increases Infectivity of the COVID-19 Virus. Cell. 2020; 182(4): 812-27.

How to cite this article: Saxena A, Gangopadhyay S, Suneja S. SARS COV-2: exploring the virus of the century. International Journal of Research and Review. 2021; 8(8): 459-467. DOI: https:// doi.org/10.52403/ijrr.20210862 